\title{
KOMPOSISI NUTRIEN TUBUH PADA KEPITING BAKAU (Scylla spp) YANG DIBERI STIMULAN MOLTING
}

\author{
Benhard Katiandagho \\ Staf Pengajar Akademi Perikanan Kamasan Biak, e-mail: bkatiandagho@ymail.com
}

\begin{abstract}
ABSTRAK
Komposisi nutrient tubuh pada kepiting bakau (Scylla sp) sangat menunjang terjadinya proses molting dengan sempurna, Penelitian ini bertujuan menganalisa pengaruh pemberian stimulant molting pada komposisi nutrien pada kepiting bakau. Penelitian ini dilaksanakan selama bulan Mei - Juli 2011 di Kabupaten Maros Provinsi Sulawesi selatan. Ada tiga perlakuan yang dicobakan yaitu A, Kontrol (tanpa vitomolt); B, Kombinasi vitomolt dosis tinggi (41.25 mg/Kg pakan) yang diberikan selama 8 hari berturut-turut lalu diberikan vitomolt dosis rendah (20.83 mg/kg pakan) hingga hari ke-60. C, Kombinasi vitomolt dosis tinggi selama 2 hari lalu diberi vitomolt dosis rendah selama 13 hari, kombinasi tersebut diulang sampai hari ke-60. Hasil penelitian menunjukkan bahwa komposisi nutrient dan energi pada kepiting bakau yang diberikan stimulant molting yaitu vitomolt memberikan komposisi nutrient dan energi yang lebih baik bagi kepiting bakau.
\end{abstract}

\section{Kata Kunci: Vitomolt, Nutrient}

\section{PENDAHULUAN}

\subsection{Latar Belakang}

Kepiting Bakau (Scylla spp) merupakan salah satu komoditas perikanan penting di Indonesia. Produksinya pada tahun 2009 mencapai 17.300 ton, dengan negara tujuan ekspor Amerika, Cina, Jepang, Hongkong, Korea Selatan, Taiwan, Malaysia, dan sejumlah negara di kawasan Eropa (Kementerian Kelautan dan Perikanan 2009). Kepiting bakau sangat prospektif dijadikan sebagai bahan pangan karena memiliki nilai nutrisi yang penting bagi tubuh, dengan kandungan nutrisi $47.5 \%$ protein dan $11.20 \%$ lemak (Karim, 2005). Daging Kepiting juga mengandung EPA dan DHA (Brown et al.,2008), unsur -unsur mineral diantaranya adalah $\mathrm{Na}, \mathrm{K}, \mathrm{Ca}, \mathrm{Mg}, \mathrm{Fe}$, $\mathrm{Zn}$, Se (Sundarrao et.al 2004). Kalsium dan magnesium adalah mineral utama dalam otot kepiting cangkang keras dan lunak (Benjakul dan Suthipan, 2008).

Perkembangan teknologi budidaya kepiting selanjutnya, cukup menjanjikan dengan munculnya produksi kepiting lunak atau shoft shell, dengan harga jualnya mencapai dua kali lipat lebih tinggi dari yang berkulit keras (Fujaya,2007). Tujuan dari budidaya kepiting lunak atau soft shell pada prinsipnya mempercepat proses molting daripada kepiting, sehingga dapat dipanen. Introduksi teknologi produksi soft shell untuk menginduksi molting dengan menggunakan ekstrak bayam (Amaranthus tricolor) ditemukan oleh Fujaya.et al.,(2007) Ekstrak bayam tersebut dikenal dengan sebutan Vitomolt. Produk dari ekstrak bayam ini mengandung fitoekdisteroid dengan profil yang sama dengan ekdisteroid pada Kepiting Bakau (Scylla spp) yang merupakan hormon molting pada kepiting. Hasil penelitian Fujaya dan Suryati (2007) menunjukkan bahwa penyuntikan vitomolt yang mengandung ekstrak bayam pada kepiting dapat mempercepat dan menyerentakan molting, tidak menyebabkan kematian.

Penelitian terkait Aplikasi vitomolt dalam pakan telah dilakukan, Aslamyah dan Fujaya (2010) menyatakan bahwa pakan buatan yang diperkaya vitomolt dengan dosis $700 \mathrm{ng} / \mathrm{g}$ kepiting mampu menstimulasi molting kepiting Bakau (Scylla spp).

Pada peneltian selanjutnya juga dikembangkan pakan kepiting dengan kadar karbohidrat dan lemak (48.89: 7,2 \%), menghasilkan pertumbuhan yang tinggi. Protein sparing effect zat gizi non protein seperti karbohidrat dapat digunakan efektif dalam mengurangi biaya pakan. Pengembangan pakan buatan bagi 


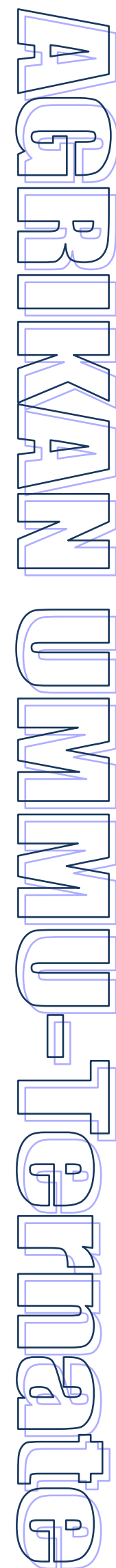

produksi kepiting cangkang lunak, merupakan salah satu solusi dalam mengurangi penggunaan pakan rucah pada budidaya kepiting cangkang lunak, karena pemberian pakan rucah dalam jangka waktu yang lama dapat memberikan dampak terhadap kualitas perairan serta menurunkan produktivitas, disamping itu ketersediaanya dalam jangka waktu panjang sangat terbatas.

Pengembangan Aplikasi pakan bervitomolt terus dilakukan dengan mengoptimalkan kinerja Vitomolt yang didasarkan pada profil ekdisteroid selama siklus molting pada Kepiting Bakau (Scylla spp). Gunamalai et al.,(2003) mengemukakan bahwa titer 20-hydroxyecdysone dalam sirkulasi bervariasi sepanjang fase molting sesaat setelah ecdysis (molting) titernya sangat rendah.

Penambahan Ekdisteroid didalam pakan sangat menunjang proses metabolisme dari setiap nutrisi yang ada oleh sebab itu didalam penelitian penggunaan vitomolt yang mengandung ekdisteroid digunakan pula untuk melihat sejauhmana pengaruhnya terhadap komposisi nutrisi tubuh kepiting bakau (Scylla,spp).

Komposisi nutrisi tubuh kepiting bakau sangat menentukan keberhasilan produktifitas kepiting cangkang lunak karena melalui analisa komposisi nutrisi tubuh maka akan diketahui fase molting yang tepat untuk pemberian pakan dengan kandungan nutrien tertentu. Kebutuhan nutrisi kepiting bakau pada setiap fase molting sangat menunjang pembentukan organ tubuh sesuai dengan fase molting tersebut.

\subsection{Tujuan Penelitian}

Penelitian ini bertujuan untuk:

1. Menganalisa komposisi nutrisi tubuh di dalam tubuh Kepiting Bakau (Scylla spp) pada setiap fase molting.

2. Menganalisis perbedaan setiap nutrien pada tubuh kepiting bakau (Scylla spp).

\subsection{Kegunaan penelitian}

Kegunaan Penelitian ini adalah memberikan informasi tentang komposisi nutrient pada tubuh kepiting bakau dalam mendukung produktivitas budidaya kepiting cangkang lunak (Soft Shell Crab).

\section{Metodologi Penelitian}

\subsection{Tempat dan Waktu Penelitian}

Penelitian ini dilaksanakan di Kecamatan Maros pada bulan Mei -Juni 2011.

\subsection{Hewan Uji}

Hewan uji yang digunakan adalah Kepiting Bakau (Scylla spp) jantan dan betina dengan ukuran lebar karapas berkisar antara 71.2- 89,3 $\mathrm{mm}$ dengan kisaran bobot badan antara 81- $90 \mathrm{~g}$. Untuk mengupayakan keseragaman hewan uji dalam penelitian ini hewan uji yang digunakan semuanya berada pada fase intermolt sejumlah 300 ekor terdiri dari 150 sampel untuk pengamatan fase molting untuk analisis proksimat dan 150 sampel untuk pengamatan molting. Hewan uji diperoleh dari suplayer Kepiting Bakau di Kabupaten Maros dan Pangkep. Propinsi Sulawesi Selatan.

\subsection{Rancangan Percobaan}

Rancangan percobaan yang digunakan adalah Rancangan Acak Lengkap. Jumlah perlakuan yang dicobakan adalah 3 perlakuan dengan 5 ulangan pada setiap ulangan terdapat 50 individu Kepiting Bakau (Scylla spp). Dengan jumlah Kepiting Bakau (Scylla spp) yang digunakan selama percobaan adalah sebanyak 150 ekor.

\subsection{Perlakuan}

Perlakuan yang akan diuji adalah :

a. Pakan buatan tanpa vitomolt diberikan selama masa pemeliharaan

b. Pakan bervitomolt dosis tinggi diberikan sampai hari ke-7, selanjutnya diberikan pakan bervitomolt dosis rendah sampai hari ke- 60

c. Pakan Bervitomolt $900 \mathrm{ng} / \mathrm{g}$ pakan diberikan pada awal pemeliharaan selama 2 hari, selanjutnya diberikan pakan bervitomolt dosis rendah selama 13 hari.

\subsection{Hormon}

Sumber hormon molting yang digunakan berasal dari ekstraksi Bayam (Amaranthaceae) yaitu Vitomolt diperoleh dari Laboratorium Bioteknologi Perikanan dan Kelautan, Pusat Kegiatan Penelitian Universitas Hasanuddin.

\subsection{Pakan Bervitomolt}

Pada penelitian ini digunakan 3 jenis Pakan yaitu :

1. Pakan buatan tanpa Vitomolt,

2. Pakan buatan yang mengandung vitomolt dengan kosentrasi rendah(450 ng/g pakan pakan), 
3. Pakan buatan yang mengandung Vitomolt dengan kosentrasi tinggi $(900 \mathrm{ng} / \mathrm{g}$ pakan pakan).

\subsection{Peubah yang diamati}

Peubah yang diamati pada penelitian ini adalah komposisi nutrisi tubuh dan energi; maka dilakukan analisa proksimat pada kepiting bakau sesuai dengan fase molting.

\section{HASIL DAN PEMBAHASAN}

Data komposisi proksimat setiap fase molting (intermolt,premolt,molt dan post molt) kepiting uji pada setiap perlakuan dengan jadwal pemberian pakan yang berbeda disajikan pada Tabel 1.

Komposisi nutrisi tubuh pada kepiting uji setiap fase molting pada Tabel 6 menunjukkan bahwa protein memiliki persentase terbesar dari nutrisi lainnya dengan persentase $34.53-64.41$ $\%$. Lemak dengan persentase $8.25-13.88 \%$, serta karbohidrat $0,88-13.66 \%$. Hal ini menunjukkan bahwa kepiting membutuhkan protein dalam jumlah yang besar pada setiap fase molting. Persentase protein dan karbohidrat menunjukkan perubahan persentase yang besar, sedangkan Lemak menunjukkan perubahan persentase yang tidak jauh berbeda.

Tabel 1. Hasil analisis proksimat terhadap komposisi nutrient

\begin{tabular}{|c|c|c|c|c|c|c|}
\hline \multirow{3}{*}{ Perlakuan } & \multirow{3}{*}{$\begin{array}{l}\text { Fase } \\
\text { Molting }\end{array}$} & \multicolumn{5}{|c|}{ Komposisi Proksimat } \\
\hline & & \multirow{2}{*}{$\begin{array}{l}\text { Abu } \\
(\%)\end{array}$} & \multirow{2}{*}{$\begin{array}{c}\text { Protein } \\
(\%)\end{array}$} & \multirow{2}{*}{$\begin{array}{c}\text { Lemak } \\
(\%)\end{array}$} & \multicolumn{2}{|c|}{ Karbohidrat } \\
\hline & & & & & $\begin{array}{c}\text { Serat kasar } \\
(\%)\end{array}$ & $\begin{array}{c}\text { BETN } \\
(\%)\end{array}$ \\
\hline Awal & Intermolt & 35.08 & 36.44 & 4.27 & 14.27 & 9.94 \\
\hline \multirow{4}{*}{ A } & Intermolt & 34.09 & 35.59 & 8.21 & 12.44 & 9.88 \\
\hline & Premolt & 34.71 & 34.53 & 6.26 & 12.42 & 12.08 \\
\hline & Molt & 14.26 & 61.98 & 11.50 & 11.18 & 1.08 \\
\hline & Post Molt & 20.80 & 61.16 & 7.00 & 10.12 & 0.92 \\
\hline \multirow{4}{*}{ B } & Intermolt & 26.49 & 48.82 & 7.33 & 8.25 & 9.11 \\
\hline & Premolt & 31.63 & 36.96 & 6.36 & 11.39 & 13.66 \\
\hline & Molt & 15.35 & 64.41 & 9.90 & 9.00 & 1.34 \\
\hline & Post Molt & 17.94 & 63.67 & 8.84 & 8.55 & 0.99 \\
\hline \multirow{4}{*}{ C } & Intermolt & 28.15 & 44.78 & 7.99 & 9.60 & 9.47 \\
\hline & Premolt & 32.54 & 36.55 & 4.03 & 13.88 & 13.00 \\
\hline & Molt & 15.06 & 60.09 & 12.61 & 11.00 & 1.24 \\
\hline & Post Molt & 19.62 & 59.91 & 8.26 & 11.33 & 0.88 \\
\hline \multirow[t]{3}{*}{ Ket: } & Pakan K & $\operatorname{tanps}$ & nolt & & & \\
\hline & ran vit & 90 & nol & roril & molt 4 & $/ q$ \\
\hline & $\begin{array}{l}\text { Pakan V } \\
\text { sampai h }\end{array}$ & $\begin{array}{l}\text { lt } 900 \\
-30)\end{array}$ & & & lakan Vitomo0l & 150 \\
\hline
\end{tabular}

\subsection{Protein}

Persentase protein pada setiap fase molting dari setiap perlakuan dapat dilihat pada Gambar 1.

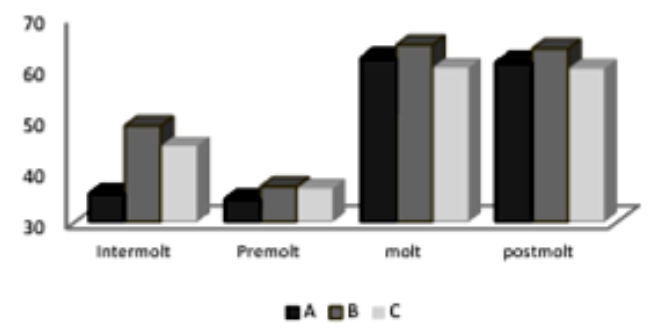

Gambar 1. Persentase protein setiap fase molting pada setiap perlakuan
Persentase protein pada fase intermolt menunjukkan adanya perbedaan nilai. Perlakuan $\mathrm{B}$ dan $\mathrm{C}$ memiliki kandungan protein yang tinggi masing-masing 48.82 dan 44.78 dibandingkan, kepiting uji yang diberi pakan kontrol dengan kandungan protein 35.59. Pemberian dosis tinggi $900 \mathrm{ng} / \mathrm{g}$ pakan pada perlakuan B (8 hari) dan perlakuan $\mathrm{C} \quad(2$ hari $)$ menunjukkan bahwa, ekdisteroid memberikan pengaruh anabolik berupa peningkatan sintesa protein dalam tubuh kepiting uji. Feldman (2009) menyatakan bahwa ekdisteroid memiliki efek anabolik dengan meningkatkan sintesa protein. Menurut Feldman (1990) periode intermolt pada kepiting sangat difokuskan pada pembentukan jaringan tubuh, pada fase ini 


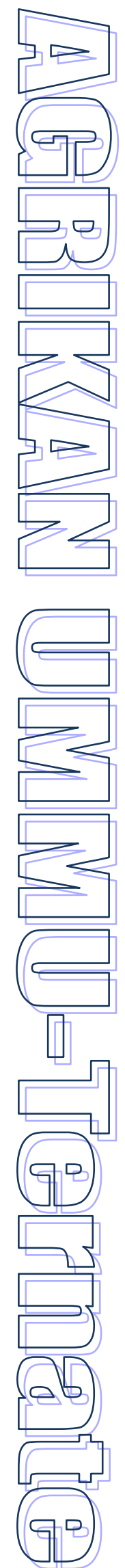

pada tubuh kepiting terjadi peningkatan sintesa protein, Semua protein yang disintesa oleh selsel digunakan untuk pertumbuhan dan mempertahankan seluruh jaringan tubuh. Berbeda dengan persentase protein pada fase molting lainnya, Persentase Protein pada fase premolt menurun pada setiap perlakuan, pada fase molt dan post molt terjadi peningkatan persentase protein yang cukup tinggi. Hal ini menunjukkan pertumbuhan yang begitu besar bagi proses molting.

\subsection{Lemak}

Persentase Lemak dalam komposisi nutrisi tubuh kepiting uji setiap fase molting pada masing-masing perlakuan disajikan pada Gambar 2.

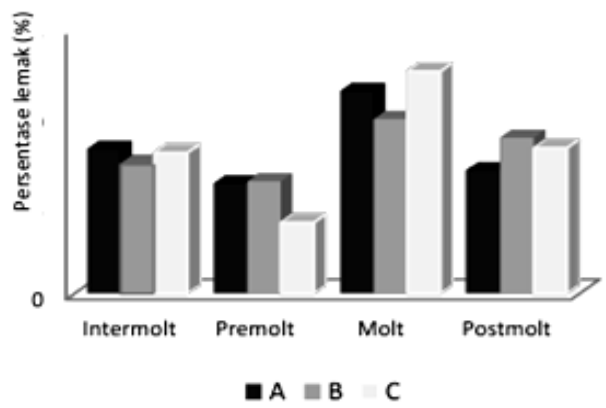

Gambar 2. Persentase Lemak (\%) setiap fase molting pada masing-masing perlakuan

Kandungan Lemak pada fase intermolt dari semua perlakuan dengan nilai persentase $(\%)$ 7.33 - 8.21, pada fase premolt persentase lemak menurun 4.03 - 6.36. Fase molt persentase lemak pada komposisi nutrisi tubuh mengalami peningkatan yang tinggi dibandingkan fase molting lainnya yaitu 9.90-12.61 \% serta menurun pada fase postmolt dengan persentase 7.00-8.84.

Perubahan persentase lemak pada setiap fase molting menunjukkan pemanfaatan lemak, sebagai sumber energi maupun pembentukan lemak tubuh. Piliang W.G (2006) menyatakan bahwa fungsi utama lemak sebagai komponen membram sel yang berfungsi sebagai sumber energi dan merupakan faktor dalam sintesa kolesterol dan berperan sebagai lemak tubuh sebagai insulator dan pelindung organ-organ penting. Perlakuan $\mathrm{C}$ dan A pada fase molt menunjukkan persentase lemak dari komposisi nutrisi tubuh yang tinggi dibandingkan Perlakuan B.

\subsection{Karbohidrat}

Persentase karbohidrat pada fase intermolt dengan persentase (\%) $9.11-9.88$ di semua perlakuan, dan meningkat pada fase premolt $12.08-13.66 \%$ hal ini menunjukkan bahwa kepiting Bakau membutuhkan energi Yang cukup tinggi pada fase premolt untuk menunjang pembentukan kutikula baru.

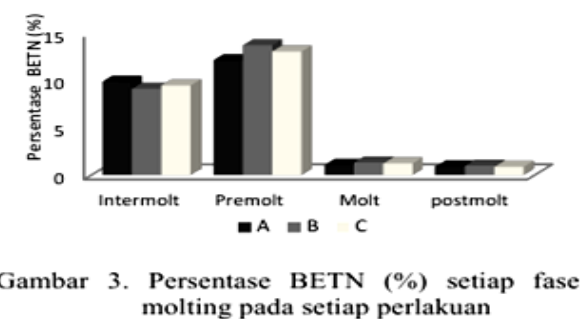

Persentase karbohidrat pada fase intermolt dengan persentase (\%) $9.11-9.88$ di semua perlakuan, dan meningkat pada fase premolt 12.08 - $13.66 \%$ hal ini menunjukkan penyediaan energi yang begitu besar bagi proses molting. Persentase karbohidrat menurun secara drastis pada fase molt $(1,08-1.34 \%)$ dan postmolt $(0,88-0,99)$, hal ini menunjukkan adanya respon pemanfaatan karbohidrat sebagai sumber energi yang cukup tinggi, pada fase molt kepiting membutuhkan energi yang tinggi untuk melepaskan eksoskeleton lama sedangkan pada fase postmolt dibutuhkan energi untuk proses pembentukan kitin. Menurut Satphaty et al.,(2003) selain untuk memenuhi kebutuhan energi, persediaan makanan di dalam tubuh, karbohidrat juga berfungsi untuk sintesis kitin pada kulit, polimerisasi kitin dan pembentukan kutikula.

\section{Kesimpulan}

1. Komposisi nutrisi tubuh pemberian pakan bervitomolt perlakuan $\mathrm{B}$ dan $\mathrm{C}$ memiliki persentase protein, karbohidrat yang tinggi pada fase intermolt dan premolt dibandingkan perlakuan $\mathrm{A}$, hal ini menunjukan bahwa vitomolt yang mengandung ekdisteroid mampu meningkatkan sintesa protein pada kepiting bakau menjelang fase molt.

2. Perbedaan persentase komposisi nutrisi tubuh kepiting bakau pada setiap fase molting menunjukkan bahwa kepiting bakau memerlukan nutrien tertentu yang menunjang proses pertumbuhan pada setiap molting. 


\section{DAFTAR PUSTAKA}

Aslamyah.S. dan Fujaya.Y 2009. Formulasi pakan buatan khusus kepiting yang berkualitas murah dan ramah lingkungan, (Special Artificial Feed Formulation of a Quality Crab, Inexpensive, and Environmentally Friendly). Fakultas Ilmu Kelautan dan Perikanan, Universitas Hasanuddin, J. Sains \& Teknologi, Agustus 2009, Vol.9 No.2 : 133 - 141.

Aslamyah.S dan Fujaya.Y ,2010. Pengembangan Pakan Buatan Khusus Kepiting Yang Berkualitas Murah dan ramah Lingkungan. Laporan penelitian Sesuai Prioritas Nasional Tahun II. Universitas Hasanuddin.

Benjakul.S, and Sutthipan.S 2009. Comparative study on chemical composition, between the muscle of hard shell and soft shell mud crabs . Food chemistry Volume 112, Copyright (C) 2008 Elsevier Ltd All rights reserved

Brown, Judith et al. 2008. Nutrition through the Life Cycle. Thomson Wadsworth. Australia. Feldman.J.I.G.2009.Phytoecdysteroids their anabolic activity. Dissertation submitted to the graduate school-New Brunswick. Rutgers, The state university of new jersey

Fujaya,Y. 2007. Mempersiapkan Kepiting Menjadi Komoditas Andalan. Fajar; tanggal 5 Mei 2007. Halaman Fujaya Y., D.D Trijuno, 2007. Profil Ecdysteroid Haemolymph dari Mud Crab (Scylla olivacea H.) selama molting dan siklus reproduksinya. Jurnal Torani. Unhas

Fujaya Y. dan Suryati., 2007. Pengembangan Teknologi Rajungan lunak hasil pembenihan dengan memanfaatkan ekstrak bayam sebagai stimulant molting. Laporan penelitian. Ristek program insentif riset terapan, MENRISTEK.

Gunamalai. V.R. Kirubagaran and T,,Subramoniam.2003. Sequesration of ekdisteroid hormone into the ovary of the Mole crab . emeriti asitica. University of Madras \& national Institute Of Ocean Technology.India

Karim, M. Y. 2005. Kinerja Pertumbuhan Kepiting Bakau Betina (Scylla serrata Forskal) Pada Berbagai Salinitas Media dan Evaluasinya Pada Salinitas Optimum Dengan Kadar Protein Pakan Berbeda (desertasi). Sekolah Pascasarjana, Institut Pertanian Bogor. Bogor

Kementerian Kelautan dan Perikanan, 2009. Kelautan dan Perikanan Dalam Angka. Marine and Fisheries in Figure.

Lafont R, Dinan L 2003. Practical uses for ekdisteroid in mammals and humans:an update.JInsect Sci 3.7.

Piliang.W. dan Djojosoebagio (2006). Fisiologi Nutrisi volume I. IPB Press Satphaty B, Mukherjee BD, Ray AK. 2003. Effect of dietary protein and Lipid Levels on growth , in rohu. Labeo rohita (Hamilton), Fingerlings .Aqua Nutrisi. 